\title{
T-Box Brain Protein 1
}

National Cancer Institute

\section{Source}

National Cancer Institute. T-Box Brain Protein 1. NCI Thesaurus. Code C102926.

T-box brain protein 1 (682 aa, $74 \mathrm{kDa}$ ) is encoded by the human TBR1 gene. This protein is involved in both transcriptional regulation and brain development. 